\title{
PENGARUH STRATEGI PEMBELAJARAN INDUKTIF (MELALUI METODE CERAMAH DENGAN METODE DISKUSI) DAN MOTIVASI BELAJAR TERHADAP PENGETAHUAN SISWA TENTANG KEANEKARAGAMAN HAYATI EKSPERIMEN DI MTS ALHIKMAH PULOGADUNG JAKARTA
}

\author{
Ani Marlina \\ animarlina8031@gmail.com
}

\begin{abstract}
The objective of this research in the find out the effect of extension strategy Inductive (lecture method vs discussion method) and the learning motivation on the student's knowledge about diversity. The strategy used was a quasi-experiment of $2 \times 2$ factorial design on the grade-VII students of Public Junior High School - Al-Hikmah Jakarta. The sample of 70 students were used, which they were divided in group. The results showed as follows; (1) there is a significant difference between the students knowledge about environment that was taught with lecture method with the students taught with the discussion method, (2) there is an interaction found between instructional inductive strategy and learning motivation on the student's knowledge about diversity, (3) the students group that process high learning motivation, their knowledge about diversity is higher with the problem solving strategy than with discussion method, and (4) the low level of learning motivation student's, their knowledge about diversity is better by lecture method than the discussion method. From the research, the conclusion is that the lecture method can be effective to increase the level of the knowledge about diversity by consideration their learning motivation.
\end{abstract}

Keywords: Knowledge about diversity, learning motivation, lecture method, extention inductive strategy 


\section{PENDAHULUAN}

Pengetahuan tentang keanekaragaman hayati dalam penerapannya diperlukan untuk mengupayakan mengembalikan fungsi-fungsi dan menjaga tanah yang rusak serta tanah yang baru dibuka agar tercapai produksi setinggi-tingginya secara lestari.

Aplikasi dan perkembangan keanekaragaman hayati merupakan suatu interaksi yang kompleks dan memiliki penyusun yang beragam. Di bumi ada bermacam-macam keanekaragaman hayati. Perkembangan keanekaragaman hayati terlihat dengan adanya perubahan-perubahan pada populasi mendorong perubahan pada komunitas. Perubahan-perubahan yang terjadi menyebabkan keanekaragaman hayati berubah. Perubahan keanekaragaman hayati akan berakhir setelah terjadi keseimbangan keanekaragaman hayati. Keadaan ini merupakan klimaks dari keanekaragaman hayati. Apabila pada kondisi seimbang datang gangguan dari luar, keseimbangan ini dapat berubah, dan perubahan yang terjadi akan selalu mendorong terbentuknya keseimbangan baru dari jenis hewan dan tumbuhan

Oleh karena itu, pentingnya pengetahuan tentang keanekaragaman hayati diterapkan pada pendidikan formal. Agar para siswa dapat berperan dan termotivasi dalam pembelajaran terhadap penciptaan keanekaragaman hayati yang seimbang.

Keanekaragaman hayati terbentuk oleh komponen hidup dan tak hidup di suatu tempat yang berinteraksi membentuk suatu kesatuan yang teratur. Keteraturan itu terjadi oleh adanya arus materi dan energi yang terkendalikan oleh arus informasi antara komponen dalam keanekaragaman hayati itu. Masing-masing komponen itu mempunyai fungsi atau relung. Selama masing-masing komponen itu melakukan fungsinya dan bekerja sama dengan baik, keteraturan keanekaragaman hayati itu pun terjaga. 
Permasalahan yang dihadapi antara lain : masih banyak siswa yang kurang memiliki pengetahuan tentang keanekaragaman hayati terhadap lingkungan, adanya pemahaman yang keliru terhadap lingkungan, belum optimalnya tingkat pendidikan dalam mempengaruhi pengetahun siswa terhadap lingkungan. Masih banyak siswa yang kurang mematuhi peraturan lingkungan sekolah dan program lingkungan hidup sekolah yang belum optimal.

World Wildlife Fund (WWF) mencatat, spesies yang terancam punah karena berbagai sebab, dalam survei yang dilakukan terhadap 47.677 jenis hewan dan tumbuhan didapati sebesar 17.291 species yang terancam punah dari muka bumi. 1/5 spesies yang terancam punah merupakan jenis mamalia dan sebagian lagi jenis reptil. Selain itu di seluruh belahan dunia kebutuhan akan air bersih semakin berkurang, jumlah spesies tanaman yang semakin berkurang. Walaupun pada tanggal 20 Juni 2015, Majelis Umum Perserikata Bangsa-Bangsa (PBB), tahun 2015 resmi memutuskan untuk mengembangkan Perjanjian Keanekaragaman Hayati terutama keanekaragaman hayati laut lepas, tetap saja membutuhkan dukungan dari seluruh umat manusia di berbagai belahan dunia untuk menyukseskannya, karena $64 \%$ keanekaragaman hayati di muka bumi adalah tanggung jawab uamt manusia.

Menurut De Cecco (2002:42) Pengetahuan merupakan hasil proses berpikir manusia yang diperoleh dari lingkunganya, berupa konsep hasil tindakan kreatif dari pemikiran manusia sebagai usahanya untuk melihat dan menjalin dengan lingkungannya. 
IJEEM: Indonesian Journal of Environmental Education and Management, Volume 2 Nomor 2 Juli 2017

Tujuan penelitian adalah untuk mengetahui perbedaan pengetahuan keanekaragaman hayati siswa yang diajar dengan strategi pembelajaran induktif melalui ceramah dan diskusi dan perbedaan pengetahuan keanekaragaman hayati siswa yang memilki motivasi kuat dan lemah dan setra pengaruh interaksi antara strategi pembelajaran induktif dan motivasi belajar terhadap pengetahuan keanekaragaman hayati siswa.

Bloom (1981:62-78), mengatakan bahwa pengetahuan dirinci menjadi Sembilan aspek yang dikelompokkan menjadi tiga kelompok, yaitu: (1) Pengetahuan terhadap hal-hal yang bersifat spesifik, meliputi: (a) terminology (istilah) da (b) fakta yang spesifik, (2) Pengetahuan tentang kaidah atau cara menangani sesuatu tentang hal-hal yang spesifik, meliputi: (c) Konvensi/kebiasaan, (d) Trend dan Sekuensi, (e) Klasifikasi dan kategori, (f) Kriteria, (g) metodologi, dan (3) pengetahuan terhadap hal-hal universal dan abstrak, meliputi: (h) prinsip dan generalisasi, (i) Teori dan struktur.

Menurut Odum (1971:80), Keanekaragaman hayati dibagi tiga yaitu Keanekaragaman genetik (genetic diversity); Keanekaragaman spesies (species diversity); dan Keanekaragaman ekosistem (ecosystem divercity). Menurut dick dan Carey (1978:108), menyebutkan bahwa terdapat lima komponen strategi pembelajaran, yaitu (1) kegiatan pembelajaran pendahuluan, (2) penyampaian informasi, (3) partisipasi peserta didik, (4) tes, dan (5) kegiatan lanjutan, yang maknanya adalah bahwa proses pembelajaran akan lebih berhasil apabila peserta didik secara aktif melakukan latihan secara langsung dan relevan dengan tujuan pembelajaran yang sudah ditetapkan. 
IJEEM: Indonesian Journal of Environmental Education and Management, Volume 2 Nomor 2 Juli 2017

Menurut Gagne dan Briggs (1979:19) Pembelajaran adalah suatu set peristiwa yang mempengaruhi siswa sehingga terjadi proses belajar. Suatu set peristiwa tersebut dapat dilakukan oleh pengajar sehingga disebut pengajaran, bias oleh siswa sendiri dengan menggunakan buku bacaan, dan berbagai macam media lainnya yang mendukung. Kedua kegiatan di atas haruslah terencana secara sistematik untuk dapat disebut kegiatan pembelajaran. Sehingga pengajaran merupakan salah satu kegiatan pembelajaran.

Ada tiga tahapan dalam teori Bruner (1999:33), tentang perkembangan intelektual yaitu: (1) Enactive, dimana seseorang belajar tentang dunia melalui aksiaksi terhadap objek, (2) Iconic, dimana pembelajaran terjadi melalui penggunaan model-model dan gambar-gambar, (3) Symbolic, yang menggambarkan kapasitas berpikir dalam istilah-istilah yang abstrak.

Strategi Pembelajaran induktif adalah satu ilmu pengetahuan yang diperlukan dalam pembelajaran tentang tekhnik yang lebih baik, yang mempelajari prinsip pendekatan sederhana serta dapat menyeimbangkan kemajuan dalam mempengaruhi pembelajaran.

Menurut Gagne (1979:91), Metode ceramah akan berhasil apabila : (a) Ada perhatian dan motivasi Belajar dari peserta didik untuk menerima bahan ajar yang disampaikan secara lisan oleh guru, (b) materi atau bahan ajar yang disusun secara sistematis terdiri atas beberapa topik/unit yang berkaita satu sama lain dan diurutkan mulai dari topik/unik yang sederhana menuju topikunit yang kompleks, (c) Alokasi waktu yang disediakan untuk metode ceramah tidak terlalu lama maksimal satu jam pembelajaran (40-45) menit, (d) suasana belajar harus menyenangkan, aman, dan terhindar dari kegaduhan sehingga peserta didik dapat menerima da memahami materi 
IJEEM: Indonesian Journal of Environmental Education and Management, Volume 2 Nomor 2 Juli 2017

yang disampaiakn dengan penuh arti, (e) Guru harus pandai melihat situasi pembelajaran sehingga bias mengatur irama pembelajaran.

Menurut Gagne (1979:98), beberapa hal yang perlu diperhatikan dalam melaksanakan diskusi sebagai metode pembelajaran adalah: (a) mempersiapkan diskusi baik tema atau topic yang akan dibahas, (b) Guru memberikan pengarahan sebelum diskusi dilaksanakan, (c) melaksanakan diskusi sesuai aturan main yang telah ditetapkan, (d) Memberikan kesempatan yang sama kepada setiap peserta diskusi untuk mengeluarkan gagasanide-idenya, (e) Mengendalikan pembicaraan kepada pokok persoalan yang dibahas, (f) Menyimpulkan hasil diskusi.

Diskusi bersifat bertukar pikiran bukan berdebat yang sifatnya argumentasi, banyak guru yang berkeberatan dengan metode diskusi karena hasil yang sulit diprediksi, memerlukan waktu panjang. Menurut Maslow mengemukakan bahwa kebutuhan itu tersusun dalam suatu hirarki. Tingkat kebutuhan dari yang paling rendah adalah kebutuhan fisiologis (Fisiological Needs), Kebutuhan akan Keselamatan dan Keamanan (Safety and Security Needs). (c) Kebutuhan akan rasa memiliki, sosial dan cinta (Social Needs). (d) Kebutuhan akan Penghargaan / Ego (Esteem Needs), dan tingkat kebutuhan yang tertinggi yaitu kebutuhan akan perwujudan diri (Self Actualization Needs).

Hubungan motivasi dengan Perilaku, Motivasi adalah satu hadiah kekuatan di manusia yang menyebabkan, penunjukan, dan perilaku pengorganisasian. Perilaku ini timbul karena akibat dorongan dengan faktor internal dan faktor eksternal. Perilaku dilihat sebagai satu reaksi atau tanggapi ke satu rangsang. 
IJEEM: Indonesian Journal of Environmental Education and Management, Volume 2 Nomor 2 Juli 2017

Menurut Petri (1981:19) sehubungan dengan motivasi atau penggerak pimpinan itu individu untuk tindak sesuai dengan daya tarik atau obyektif dicapai yang mempunyai tiga karakteristik, yaitu: 1. Intensitas (Intencity); mengaitkan dorongan lemah dan kuat menyebabkan individu tertentu berkelakuan; 2. Memberikan arah (Giving directions); penunjukan perorangan di dalam menghindari atau laksanakan satu perilaku tertentu; 3. Ketekunan (persistance) atau kecenderungan untuk mengulangi perilaku secara terus-menerus.

\section{METODE}

Metode Penelitian yang digunakan adalah metode eksperimen karena menguji perbandingan, dengan variabel terikat pengetahuan siswa tentang keanekaragaman hayati. Variabel bebas perlakuan adalah strategi pembelajaran induktif yang terdiri atas strategi metode ceramah dan metode diskusi. Sedangkan variabel bebas atribut adalah motivasi pembelajaran kuat dan lemah.

Adapun desain penelitian yang digunakan adalah faktorial sederhana (simple factorial design) $2 \times 2$ dengan matrik rancangan eksperimen yang diadaptasi dari John W. Best yang ditunjukkan pada tabel 3.1 berikut :

Tabel 1. Desain Treatmen by Level $2 \times 2$

\begin{tabular}{|l|c|c|}
\hline Motivasi Belajar & $\begin{array}{c}\text { Pembelajaran } \\
\text { Induktif Metode } \\
\text { ceramah } \\
\left(\mathrm{A}_{1}\right)\end{array}$ & $\begin{array}{c}\text { Pembelajaran } \\
\text { Induktif Metode } \\
\text { Diskusi } \\
\left(\mathrm{A}_{2}\right)\end{array}$ \\
\hline $\begin{array}{l}\text { Motivasi Belajar Kelompok } \\
\text { Kuat }\left(\mathrm{B}_{1}\right)\end{array}$ & $\mathrm{A}_{1} \mathrm{~B}_{1}$ & $\mathrm{~A}_{2} \mathrm{~B}_{1}$ \\
\hline $\begin{array}{l}\text { Motivasi Belajar Kelompok } \\
\left.\text { Lemah ( } \mathrm{B}_{2}\right)\end{array}$ & $\mathrm{A}_{1} \mathrm{~B}_{2}$ & $\mathrm{~A}_{2} \mathrm{~B}_{2}$ \\
\hline
\end{tabular}


Keterangan :

$\mathrm{A}_{1} \mathrm{~B}_{1}$ : Kelompok siswa yang memiliki Motivasi belajar kuat dengan perlakuan startegi induktif metode ceramah

$\mathrm{A}_{2} \mathrm{~B}_{1}$ : Kelompok siswa yang memiliki motivasi belajar kuat dengan perlakuan startegi induktif metode diskusi

$\mathrm{A}_{1} \mathrm{~B}_{2}$ : Kelompok siswa yang memiliki motivasi belajar lemah dengan perlakuan startegi induktif metode ceramah

$\mathrm{A}_{2} \mathrm{~B}_{2}$ : Kelompok siswa yang memiliki motivasi belajar lemah dengan perlakuan startegi induktif metode diskusi

Rancangan faktorial adalah unit-unit eksperimen dikelompokkan ke dalam sel sedemikian rupa secara acak, sehingga unit-unit eksperimen dalam setiap sel relatif bersifat homogen. Sampel ditempatkan secara acak sederhana ke setiap unit-unit eksperimen dalam setiap sel.

Ketiga variabel penelitian dibandingkan dalam satu rancangan penelitian seperti yang digambarkan pada Tabel 3.1 di atas. Data yang diperoleh melalui instrumen penelitian, digunakan untuk memeriksa kemungkinan adanya perbedaan antar variabel karena adanya perlakuan dengan mengadakan pengontrolan terhadap variabel lain yang akan mempengaruhi variabel-variabel yang sedang diteliti.

\section{HASIL}

Untuk menyelesaikan masing-masing uji hipotesis akan digunakan adalah uji analisis varians (ANAVA) untuk hipotesis pertama, kedua, dan kelima. Untuk hipotesis ketiga dan keempat yang diusulkan adalah uji dua kelompok dengan menggunakan uji Tuckey, maka hipotesis tersebut akan diuji lanjut Hasil uji pengaruh strategi pembelajaran induktif dan motivasi belajar terhadap pengetahuan siswa tentang keanekaragaman hayati terdapat pada hasil uji beda dua kelompok dan interaksi menggunakan uji Anava dapat dilihat pada tabel sebagai berikut : 
Tabel 2. Hasil Perhitungan Dua Arah (two-way ANOVA)

\begin{tabular}{|l|r|c|r|r|l|}
\hline Sumber Varians & \multicolumn{1}{|c|}{ JK } & $\mathbf{d k}$ & $\mathbf{R J K}$ & $\mathbf{F}_{\text {hitung }}$ & F $_{\text {tabel }}$ \\
\hline Antar A & 264.06 & 1 & 264.06 & $\mathbf{1 5 . 6 6}^{\star \star *}$ & $\mathbf{0 , 0 0 1}$ \\
\hline Antar B & 177.94 & 1 & 177.94 & $\mathbf{1 0 . 5 5}^{\star \star *}$ & \\
\hline Interaksi AXB & $\mathbf{2 8 0 . 0 6}$ & $\mathbf{1}$ & $\mathbf{2 8 0 . 0 6}$ & $\mathbf{1 6 . 6 1}^{\star \star *}$ & \\
\hline Dalam (D) & 1079.18 & 64 & 16.86 & & \\
\hline Antar Kelompok & 722.06 & 3 & 240.69 & $\mathbf{1 4 . 2 7}^{\star \star *}$ & \\
\hline Total (T) & 1801.24 & 67 & & & \\
\hline
\end{tabular}

*** $p<0,001$

Hipotesis Pertama, hipotesis statistik tersebut dirumuskan dalam pernyataan sebagai berikut: bahwa pengetahuan siswa tentang keanekaragaman hayati yang memiliki strategi pebelajaran induktif melalui ceramah lebih baik dari pada pengetahuan siswa tentang keanekaragaman hayati yang memiliki strategi pebelajaran induktif melalui diskusi. Pengujian hipotesis pertama dilakukan dengan menggunakan uji Anava dua arah. Kriteria yang ditentukan adalah: tolak Ho jika harga $F$ hitung lebih besar dari signifikan pada $\alpha=0,001$. Dengan menggunakan perhitungan di peroleh hasil uji. Berdasarkan hasil uji pada Tabel Anava tersebut, apabila $\alpha<$ sig., maka Ho ditolak, sebaliknya bila $\alpha \geq$ sig., maka Ho diterima. Hasil uji pada Tabel Anava tersebut, hasilnya menunjukkan bahwa Fhitung $=15.66>$ Ftabel $=0,001$ adalah sangat signifikan. Jadi kesimpulannya Ho ditolak. Hal tersebut memberikan bukti secara empirik bahwa hipotesis pertama dalam penelitian ini teruji secara sangat signifikan

Hipotesis Kedua, hipotesis statistik, dirumuskan dalam kalimat pernyataan sebagai berikut: bahwa pengetahuan siswa tentang keanekaragaman hayati bagi motivasi belajar kuat lebih baik dari pada pengetahuan siswa tentang keanekaragaman hayati bagi motivasi belajar lemah. Pengujian hipotesis pertama dilakukan dengan menggunakan uji Anava Dua Arah. Dengan menggunakan perhitungan. Berdasarkan 
hasil uji pada Tabel Anava, Apabila $\alpha<$ sig., maka Ho ditolak, sebaliknya bila $\alpha \geq \operatorname{sig}$, maka Ho diterima. Ternyata hasil analisis menunjukkan bahwa $\mathrm{F}$ hitung $=10.55>\mathrm{F}$ tabel $=0,001$ adalah sangat signifikan. Jadi kesimpulannya Ho ditolak. Hal ini berarti bahwa wawasan lingkungan siswa wanita lebih baik ari pada wawasan lingkungan siswa pria. adalah signifikan. Hal tersebut memberikan bukti secara empirik bahwa hipotesis kedua dalam penelitian ini teruji sangat signifikan.

Hipotesis Ketiga, hasil uji hipotesis ini dapat dilihat di tabel berikut,

\begin{tabular}{|c|c|c|c|c|}
\hline \multirow{2}{*}{ Pasangan Kelompok } & \multirow{2}{*}{ QHitung } & \multicolumn{2}{|c|}{ Qtabel } & \\
\cline { 3 - 4 } & & $\mathbf{0 . 0 5}$ & $\mathbf{0 . 0 1}$ & Kesimpulan \\
\hline A1B1 dengan A2B1 & 8.03 & 3.74 & 4.59 & Signifikan \\
\hline A1B2 dengan A2B2 & 0.12 & 3,74 & 4,59 & Signifikan \\
\hline
\end{tabular}

Dapat dilihat dalam tabel di atas bahwa dapat diprediksi akan memberikan hasil yang signifikan maka pada kelompok siswa yang memiliki strategi pembelajaran induktif melalui metode ceramah tentang keanekaragama hayati lebih baik dari pada strategi pembelajaran induktif melalui metode ceramah tentang keanekaragama hayati. Ternyata hasil data yang dianalisis menunjukkan bahwa Qhitung 8,03 > Qtabel 3,74 Jadi kesimpulannya siqnifikan artinya pengetahuan siswa tentang keanekaragaman hayati lebih baik dari pada pengetahuan siswa tentang keanekaragaman hayati.

Hipotesis Keempat, hasil uji hipotesis ini diprediksi akan memberikan hasil yang signifikan maka pada kelompok siswa yang memiliki strategi pembelajaran induktif melalui diskusi pengetahuan keanekaragaman hayati siswa lebih baik dari pada pengetahuan siswa tentang keanekaragaman hayati melalui ceramah. Ternyata hasil 
data yang dianalisis menunjukkan bahwa Qhitung 0,12 > Qtabel 3,74 Jadi kesimpulannya pengetahuan siswa tentang keanekaragaman hayati bagi motivasi belajar kuat pada pengetahuan siswa tentang keanekaragaman hayati pada strategi pembelajaran induktif melalui diskusi.

Hipotesis Kelima, hipotesis statistik tersebut, dirumuskan dalam pernyataan sebagai berikut: Terdapat interkasi antara strategi pembelajaran induktif dengan motivasi belajar terhadap pengetahuan siswa tentang keanekaragaman hayati. Pengujian hipotesis kedua dilakukan dengan menggunakan uji Anava Dua Arah. Kriteria pengujian adalah: terima Ho jika harga $F$ hitung tidak signifikan pada $\alpha=0,001$. Berdasarkan hasil perhitungan dengan menggunakan perhitungan. Hasil uji pada Tabel Anava tersebut, Apabila $\alpha<$ sig., maka $\mathrm{H} 1$ diterima. Sebaliknya bila $\alpha \geq$ sig, maka Ho ditolak. Hasil perhitungan pada hipotesis ini menunjukkan bahwa $F$ hitung $16,61<F$ tabel 0,001 adalah sangat signifikan. Jadi kesimpulannya Ho ditolak. Dengan demikian, uji hipotesis kelima yang menyatakan bahwa terdapat pengaruh interaksi strategi pembelajaran induktif dan motivasi belajar terhadap pengetahuan siswa tentang keanekaragaman hayati adalah terbukti secara signifikan. Hasil uji ini memberikan bukti bahwa secara empirik hipotesis kelima yang menyatakan bahwa terdapat interaksi antara strategi pembelajaran induktif da motivasi belajar terbukti.

Strategi pembelajaran sangat bervariasi, namun pada penelitian ini difokuskan pada strategi pembelajaran induktif, yaitu strategi pembelajaran induktif melalui ceramah dan strategi pembelajaran induktif melalui diskusi. Dua strategi pembelajaran induktif tersebut telah diketahui memberikan pengaruh yang signifikan dalam membentuk pengetahuan siswa tentang keanekaragaman hayati. Siswa yang memiliki strategi pembelajaran induktif melalui ceramah juga memiliki pengetahuan siswa 
tentang keanekaragaman hayati yang lebih baik dibandingkan dengan siswa yang memiliki strategi pembelajaran induktif melalui diskusi. Peran motivas belajar dalam mempengaruhi pengetahuan ilmiah dan kepedulian lingkungan telah lama ditelaah oleh sosiologist dan environmentalist. Dalam hasil penelitian ini diketahui bahwa siswa yang memiliki motivasi belajar kuat yang lebih baik dibandingkan dengan siswa yang mempunyai motivasi belajar lemah. Strategi pembelajaran induktif dan motivasi belajar memberikan pengaruh secara independen terhadap pengetahuan siswa tentang keanekaragaman hayati.

\section{KESIMPULAN}

Kesimpulan yang dapat diperoleh dari penelitian ini adalah pengetahuan siswa yang menggunakan strategi pembelajaran induktif melalui ceramah lebih baik dari pada pengetahuan siswa yang menggunakan strategi pembelajaran induktif melalui diskusi, maka demikian pula pengetahuan siswa tentang keanekaragaman hayati dengan motivasi belajar kuat lebih baik dari pada pengetahuan siswa tentang keanekaragaman hayati dengan motivasi belajar lemah. Pada strategi pembelajaran induktif melalui ceramah pengetahuan siswa tentang keaekaragaman hayati kelompok motivasi belajar kuat lebih tinggi dari pada pengetahuan siswa tentang keaekaragaman hayati kelompok motivasi belajar lemah. Pengetahuan siswa tentang keanekaragaman hayati dengan motivasi belajar kuat lebih tinggi daripada pengetahuan siswa tentang keanekaragaman hayati dengan motivasi belajar lemah. 


\section{DAFTAR PUSTAKA}

Addison, P.A. dan Hutcheson, V.K. The Importance of Prior Knowledge to New Learning. http://cea.curtin.edu.au/tlf/tlf2001/addison.htmi, 2001.

Anderson, Orin W. And david R. Krathwohl. A Taxonomy for Learning, Teaching, ans Assesing. New. York: Addison Wesley Longman, Inc., 2001.

Bernhard Gramlich, Article Journal International. Strategic Issues, Problems and Challenges in Inductive Theorem Proving. Fakultat fur Informatik, Tu Wien Favoritenstr.9 - E185/2, A-1040 Wien, Austria.

Bloom, Benjamin S. Et. Al. Taxonomy of Educational Objectives: The Classification of Educational Goals. London: Longman Group Ltd., 1981.

Bruce, Joyce. Models of Teaching.6th Ed. London: Allyn \& Bacon, 2000.

Bruce, Joyce, dan Marsha weil. Models of Teaching, 5th edition. Needham Heights, Mass 02194: Asimon \& Schuster Company, 1996.

Best, Research in Education, New Delhi : Prentice Hall of India Private Limited, 1982.

Bloom (ed), Taxonomy of Educational Objektives, London: Longman LTD. 1979.

Chiappetta, Eugene L \& Koballa Jr, Thomas R. Science Intruction in The Middle and Secondary Schools Developing Fundamental Knowledge and Skill. Boston: Pearson Education Inc., 2010.

Chiras, Environmental Sciens: Action for a Sustainable Future, Redwood City: The Benjamin cummings Publishing Company. 1991.

David, Sthepen Ross. Moral Decision and Introduction to Ethics. USA Freeman, Cooper \& Co., 2002.

De Cecco, John P., The Regenaration of The Readings in Educational Psychology, Sociology and Politics. New York: Holt Rinehart and Winston, Inc., 2002. 
Dick, Walter and Lou Carey. The systematic Design of Intructio. New York: Harper Collins College Publisher, 2000.

Gagne, Robert M. dan Leslie J. Briggs. Principles of instructional Design, $4^{\text {th }}$ edition. New York: Holt, Rinehart and Wiston, 1992.

Gagne, Robert M. The Condition Learning, New York: Holt, Rinehart and Wiston, 1974.

Gagne, Robert M. N. L and David C. Berliner. Educational psycology. Third Edition Boston: Houngton Mifflin Company, 1984.

Hopkins, Kenneth D and Gene V Glass. Basic statistics for the Behavioral science. New Jersey: Prentice-Hall, 1978.

Jerome S Bruner. The Process of Education. Harvard University, Press Cambridge, Massachusetts, London England, 1999.

Kitano, M. K. \& Kirby, D.F. Gifted Education Psychology of the Gifted. New York: McMillan Publicatio Co., 1986.

Leshin, Cynthia B, Joellyn P. dan C.M Reigeluth. Instructional Design Strategy and Tactics. Englewood Clifts. NJ.: Educational Technology Publication, 2002.

Odum, Eugene P. Fundamentals of Ecology, Philadelpia: W.B. saunders Company, 1991.

Petri, H.L. Motivation Theory and Research, Wadsworth publishing company, Belmont, California, 1981.

Pearsall, N.R. Knowledge Restructuring in the Life Science: A Longitudinal Study of Conceptual Change in Biology. USA: John Willey and Son., 2002.

Russel dkk, Instructional Media and the new Technology of Instruction, New York: Mc Millan Publishing Company, 1989). 
Reigeluth, Charles M. Instructional Design Theories and Model. New York: COntese Erl Braum Assciartes Pub, 1983.

Reigeluth, Charles m, C. Victor Baunderson dan M. David Merril. What is the Design Science of Intruction, Journal of Intruction Development, Vol 1. No. 2, 1978.

Romiszowski, A.J. Designing Instructional System. New York: Nichols Publishing Company, 2001.

Seels, Barbara B and Rita C. Richey. Instructional Technology: The Definition and Domains the Field. Washington, DC: AECT, 2004.

Veitch, Russel and Daniel Arkkelin. Environmental Psychology, An Interdiciplinary Perspective. New Jersey: Prentice-Hall Inc, 1995.

Woolfolk, Educational Psychology Active Learning Edition, Yogyakarta : Pustaka Pelajar, 2009. 